\title{
The childhood obesity strategy
}

\author{
Disappointment all round
}

\section{Cécile Knai associate professor of public health policy, Mark Petticrew professor of public health evaluation, Nicholas Mays professor of health policy}

Faculty of Public Health and Policy, London School of Hygiene and Tropical Medicine, London WC1H 9SH, UK

The UK government's policy document Childhood Obesity: A Plan for Action presents itself as "the start of a conversation rather than the final word." "This will be a relief to many given the criticism it has received for its lack of ambition, including from food retailers and manufacturers. ${ }^{2-5}$

The strategy, published on 18 August, includes the previously announced industry levy on soft drinks, which will require companies to pay a charge for drinks with added sugar and total sugar content $\geq 5 \mathrm{~g} / 100 \mathrm{~mL}$, and a higher charge for the drinks that contain $\geq 8 \mathrm{~g} / 100 \mathrm{~mL}$. Voluntary reformulation of selected products to remove $20 \%$ of sugar and a voluntary healthy rating scheme for primary schools, in which schools will be encouraged to show what progress they are making towards tackling obesity, are also included, along with support for the voluntary food guidelines in early years settings.

The strategy also encourages compliance with the existing school food standards, which aim to ensure that pupils are provided with high quality food. It emphasises the need for more school physical activity and mentions revised food labelling programmes to provide better information to consumers-for example, it suggests labels might show the teaspoons of sugar contained in packaged food and drink. The strategy omits controls on the marketing and price promotion of unhealthy foods ${ }^{3}$ recommended by Public Health England. ${ }^{6}$

Aside from the levy, the strategy relies on voluntary action. This has been repeatedly shown to be relatively ineffective in changing industry or consumer behaviour or in improving public health. The previous attempt to improve public health "further, faster and at lower cost," the Public Health Responsibility Deal, ${ }^{78}$ was launched by the coalition government in England in 2011 as a voluntary, pledge based, partnership between government, business, the public sector, and non-governmental organisations. It was dominated by businesses, ${ }^{7}$ which seem to have participated mainly to meet their corporate social responsibility commitments, enhance their reputations, and reduce the possibility of regulation. ${ }^{8}$ Most businesses committed to activities they were already undertaking, ${ }^{8}$ and the resulting pledges were largely not underpinned by evidence of effectiveness. ${ }^{7}$
Retailers and manufacturers now seem to want stronger measures, partly to achieve a "level playing field" for their business. ${ }^{8}$ The chief executive of supermarket chain Sainsbury's stated that the strategy "needs to be tougher" and requires "compulsory and measured targets for the reduction of sugar (and other nutrients such as saturated fats) across the whole of the food and drink industry. Nothing less will work. We have seen this with voluntary targets on reformulation and labelling, which led to a piecemeal response from business." "The British Retail Consortium adds that "only laws would achieve the $20 \%$ reduction in sugar demanded by the government's plans." ${ }^{5}$ This seems to be part of a broader call by food and drinks multinationals for stronger measures. For example, in a recent open letter, major food companies appealed to the European Commission to consider legislating to limit the content of industrially produced trans-fatty acids in foods. ${ }^{9}$

The childhood obesity plan could be greatly strengthened. Beyond the sugar levy, which is backed by good evidence, ${ }^{10}$ mandatory measurable targets that go beyond "business as usual" 11 should be set to reduce sugar in food products (and saturated fat, though this is largely absent from the action plan) significantly; it appears that these would be largely supported by industry. There are, however, preconditions for effective reformulation. Firstly, reformulation targets must be directly informed by the scientific evidence. Secondly, reformulation must entail reduction in existing products rather than the creation of additional low sugar (and low fat) alternatives. Thirdly, beyond reviewing progress every six months, Public Health England should require formal reporting against clear measurable targets, systematic monitoring, and regularly updated public reports. Evaluation of the responsibility deal found that progress reports were not consistently submitted and were mostly incomplete and vague because clear measurable targets had usually not been set. ${ }^{7}$

Supporting the school food standards for healthier school meals is essential, but given the importance of nutrition in 1-5 year olds for growth and development, early years settings should also be given mandatory food standards instead of voluntary guidelines. The evidence shows that reduced marketing and price promotion of unhealthy foods is fundamental, as 
promotions and advertising directly shape purchasing and consumption choices. ${ }^{6}$ This includes avoiding food and drink industry sponsorship of community physical activity or sporting events, as they are powerful ways of influencing brand recognition and intention to consume the sponsor's product, rather than increasing physical activity itself. ${ }^{12}$

Competing interests: We have read and understood BMJ policy on declaration of interests and declare that we were part of the academic research team at LSHTM that conducted the independent evaluation of the responsibility deal, which was funded by the Policy Research Programme of the Department of Health for England via its core support for the Policy Research Unit in Policy Innovation Research (PIRU). See: http://www.piru.ac.uk/projects/current-projects/public-healthresponsibility-deal-evaluation.html.

Provenance and peer review: Commissioned; not externally peer reviewed.

1 HM Government. Childhood obesity: a plan for action. 2016. https://www.gov.uk government/uploads/system/uploads/attachment_data/file/546588/Childhood_obesity_ $2016 \quad 2$ acc.pdf. 2016.

2 Faculty of Public Health. Childhood obesity plan lets down children. 18 Aug 2016. http:// www.fph.org.uk/childhood_obesity_plan_lets_down_children. 2016

3 UK Health Forum. Government obesity plan is a first step but fails to deliver essential package of bold actions. UK Health Forum, 17 Aug 2016. http://nhfshare.heartforum.org
uk/RMAssets/NHFpositionstatements/UKHF_responsetoObesity_Strategy_Launch_17_ August 2016.pdf. 2016

4 Quinn I. Soft drinks levy and school sport at heart of government's childhood obesity strategy. The Grocer 2016;18:2016.

5 Smyth C. Make us sell healthy food, supermarkets implore May. Times 2016 Aug 19 http: //www.thetimes.co.uk/article/make-us-sell-healthy-food-supermarkets-implore-mayz8t8z0stp.

6 Public Health England. Sugar reduction: the evidence for action. 2015. https://www.gov. uk/government/uploads/system/uploads/attachment data/file/470179/Sugar_reduction The_evidence_for_action.pdf

7 Knai C, Petticrew M, Durand M, et al. Has a public-private partnership resulted in action on healthier diets in England? An analysis of the public health responsibility deal food pledges. Food Policy 2015;54:1-10doi:10.1016/j.foodpol.2015.04.002.

8 Durand MA, Petticrew M, Goulding L, Eastmure E, Knai C, Mays N. An evaluation of the Public Health Responsibility Deal: Informants' experiences and views of the development, implementation and achievements of a pledge-based, public-private partnership to improve population health in England. Health Policy 2015;119:1506-14. doi:10.1016/j.healthpol. 2015.08.013pmid:26433565.

9 BEUC, CPME, EHN, et al. Open letter: call for a legislative limit for the amount of industrially produced TFAs in foods. 15 Oct 2015. http://epha.org/open-letter-call-for-alegislative-limit-for-the-amount-of-industrially-produced-ffas-in-foods/

10 Cornelsen L, Carriedo A. Health-related taxes on foods and beverages. Food Research Collaboration policy brief. 2015. http://foodresearch.org.uk/wp-content/uploads/2015/06/ Food-and-beverages-taxes-final-amended.pdf

11 Bryden A, Petticrew M, Mays N, Eastmure E, Knai C. Voluntary agreements between government and business-a scoping review of the literature with specific reference to the Public Health Responsibility Deal. Health Policy 2013;110:186-97. doi:10.1016/j. healthpol.2013.02.009pmid:23506799.

12 Carter MA, Signal L, Edwards R, Hoek J, Maher A. Food, fizzy, and football: promoting unhealthy food and beverages through sport-a New Zealand case study. BMC Public Health 2013;13:126. doi:10.1186/1471-2458-13-126pmid:23399019.

Published by the BMJ Publishing Group Limited. For permission to use (where not already granted under a licence) please go to http://group.bmj.com/group/rights-licensing/ permissions 